\title{
Reflections on participant research with young people in a low-income community
}

Danilo de Miranda Anhas ${ }^{1}$, Carlos Roberto de Castro-Silva ${ }^{2}$

\begin{abstract}
Participant research seeks to value the experiences and knowledge of the other, in which the researcher has an ethical and social commitment, breaking with the traditional subjectobject dichotomy existing in the positivist paradigm. This participatory approach seeks and engages ethically and politically with social transformation. This study seeks to discuss and reflect on the contributions of participant research in the construction of intersubjective links and in the construction of knowledge about the living conditions of young people in a community on the outskirts of a medium-sized municipality on the coast of the state of São Paulo, Brazil.
\end{abstract}

\section{Keywords}

Participant Research. Intersubjectivity. Young People.

\footnotetext{
${ }^{1}$ PhD student in Health Sciences, Federal University of São Paulo, Baixada Santista Campus, Brazil with sandwich period at the University of Lisbon, Portugal. E-mail: danilo-anhas@ hotmail.com.

${ }^{2}$ Postdoctorate in Social Sciences, University of Western Ontario, Canada; assistant professor at the Federal University of São Paulo, Baixada Santista Campus, Brazil. E-mail: carobert3@ hotmail.com.
} 


\section{Reflexões sobre a pesquisa participante com jovens em uma comunidade periférica}

Danilo de Miranda Anhas ${ }^{3}$, Carlos Roberto de Castro-Silva ${ }^{4}$

\section{Resumo}

A pesquisa participante busca a valorização das experiências e do saber do outro, na qual o pesquisador possui um compromisso ético e social, rompendo com a tradicional dicotomia existente no paradigma positivista entre sujeito e objeto. Esta abordagem participativa busca e compromete-se ética e politicamente com a transformação social. Este estudo busca discutir e refletir sobre as contribuições da pesquisa participante na construção de vínculos intersubjetivos e na construção do conhecimento sobre as condições de vida de jovens em uma comunidade da periferia de um município de médio porte no litoral do estado de São Paulo, Brasil.

\section{Palavras-chave}

Pesquisa Participante. Intersubjetividade. Juventude.

\footnotetext{
${ }^{3}$ Doutorando em Ciências da Saúde pela Universidade Federal de São Paulo, Campus Baixada Santista, Brasil com período sanduíche na Universidade de Lisboa, Portugal. E-mail: danilo-anhas@ hotmail.com.

${ }^{4}$ Pós-doutorado em Ciências Sociais pela University of Western Ontario, Canadá; professor adjunto da Universidade Federal de São Paulo, Campus Baixada Santista, Brasil. E-mail: carobert3@ hotmail.com.
} 


\section{INTRODUCTION}

Participant research is a participatory methodology and, according to authors such as Fals Borda (2006) and Paulo Freire (2011), its historical roots are theoretically connected to Marxism as well as to an ethical-political choice of fighting for the transformation and liberation of Latin American people through collective social action (STRECK, 2016). This way of doing research takes into account our history as colonies and seeks, through the production of knowledge and the establishment of bonds, the transformation and emancipation of our condition of subservience to foreign interests, which today, more than ever, is associated with neoliberalism, which favors the breakdown of social ties (DARDOT; LAVAL, 2016).

Martín-Baró's studies (2017) are interesting examples of this quest for social transformation and commitment to the other. In addition to reflecting on participatory methodologies, the author points out the importance of producing our own knowledge based on our history and not uncritically importing theoretical-methodological models from other realities and contexts.

In this direction, in addition to the researcher's ethical and political commitment to the other and to the reality studied, participant research becomes feasible insofar as it can involve individuals through the exercise of dialogue (FREIRE, 2011) and the valorization of their experiences. In other words, this way of doing research is made feasible when intersubjective links are established out of dialogue, horizontal relations, affects, being articulated to a political dimension committed to social transformation (MENDES; FRUTUOSO; CASTROSILVA, 2017).

For other authors working with this approach, the construction and production of knowledge consist, as mentioned, in collective acts (SILVA; SOUZA, 2014; STRECK, 2016). According to Silva and Souza (2014), based on the works of Carlos Rodrigues Brandão, knowledge building is a dialectical process in which teaching and learning are parts of the same work. Thus, during the process of teaching and learning, in a horizontal logic of relationships, the individuals involved transform and are transformed. This confronts the other logic, much criticized by Freire (2011), based on instrumental rationality, in which vertical relations are constructed where one teaches and the other learns. 
Studies that use the participatory research approach often emphasize the importance of building intersubjective connections based on horizontal relationships with individuals, valuing the knowledge and experience they have (MENDES; FRUTUOSO; CASTROSILVA, 2017; MORAES et al., 2017). Studies that use this approach are quite diversified, with productions in the area of health and, mainly, education.

The investigative work in participant research implies an intense affective involvement with the communities and individuals trying to understand their history and culture intersubjectively, in a constant exercise of building bonds. In the process of building bonds, there is a need to produce asymmetric relationships that take into account the knowledge of the other (FALS BORDA, 2006; FREIRE, 2006; MORAES et al., 2017). Participating here implies putting oneself in motion, following and placing oneself in the dynamics of the social reality studied, reflecting on the bonds built with the individuals throughout the fieldwork.

However, it must be taken into account that any researcher and study participants are always crossed by power relations, running the risk of research reinforcing asymmetric relations and losing its transformative potential. Thus, researching in this perspective involves recognizing the social and institutional places one occupies as a researcher, who is not a part of the studied context, but has an ethical and political commitment to it. It is necessary to analyze and reflect on one's own practice and there are few studies about researchers who propose the challenge of reflecting on their own activity in research (CRUZ-GARCETTE; ABREU BALLESTER; BRANDI-BRUNA, 2014).

Commitment to the other has ethical dimensions. Schmidt (2008) reflects on the attitudes she considers important in the researcher's ethical training process. Dialogue, otherness, empathy, democratic distribution of decision making, talks, reflections, respect for individuals' ways of living, ethical care with textual production during and after fieldwork, giving credit to the participants. In this sense, it is necessary to reflect if participant research would not be the critical exercise of a democratic practice of valuing the diversity, knowledge and participation of the other through intersubjective ties established during the fieldwork.

In the case of studies with and on youth, it is possible to ask if participant research is able to construct other possibilities in the approach to this population. Brazilian public policies aimed at young people reinforcing their status as pre-citizens, historically in a guardianship situation 
(HORTA; SENA, 2010), who are often approached as at-risk and socially endangered groups (MALVASI; TRASSI, 2010).

We recall that participant research seeks to break with the subject-object dichotomy, since it believes that there is no neutrality; the researcher himself becomes the object of his study; and the individuals (or community), who would be regarded as objects in a positivist paradigm, are active subjects in the production of knowledge (STRECK, 2016). Thus, conducting participatory research with young people from a community in the Brazilian periphery constitutes a way of valuing this diversity and the participation of those who, in our society, are historically placed in a condition of pre-citizenship, guardianship and control, according to Castro (2009). Participatory methodologies can, as Onocko-Campos (2011) points out, talk with young people and not reinforce socially constructed ideas that keep young people in subalternity and speak by them.

This article refers to a research in progress in a community in Cubatão, where we have been working since 2012 via a public Health Unit. The Health Unit is an institution that acts in the scope of Primary Health Care, constituting one of the levels of the National Health Service in Brazil. We have produced papers that reflect on the contributions of participant research in the construction of knowledge. Moraes et al. (2017) emphasize in these works the importance of dialogue and the construction of horizontal relations with health professionals and community, highlighting insertion in the community as a starting point for the construction of bonds with a view to social transformation. We agree here with Lane (2004) and we approach the sense of transformation as one of denaturing of social and historical phenomena.

In order to enter and act in the context, a theoretical background is required that is not separate from practice (LANE, 2004). Lane (2004) and Streck (2016) also point out that it is always necessary to reflect on the practice itself and that this exercise is not dissociated from theoretical reflection. In addition, it is necessary to have theoretical sensitivity, i.e., the ability to read and pronounce the world through theories (STRECK, 2016), and not only to use knowledge previously constructed by other authors, but to produce new knowledge (REY, 2012) based on reality and a specific historical context. To enter the historical context is to participate in it, and since the social reality is dynamic and changeable, it is necessary to put oneself in motion too, to be and to integrate the very process of knowledge construction. 
However, such placement brings dilemmas and problems that we will try to address in the results section of this article, which aims to discuss and reflect on the contributions of participant research in the construction of intersubjective bonds and the construction of knowledge about the living conditions of young people in a community on the outskirts of Cubatão. It is important to note the scarcity of participatory research studies on the young population in low-income communities, which seems to reproduce a conception of youth considered as insubordinate, who would not be able to produce knowledge. Youth would then always be the target of actions and not co-partaking of these.

\section{METHODOLOGY}

We have used Depth Hermeneutics in our analyses, as proposed by Thompson (2011), based on authors such as Paul Ricouer and Jurgen Habermas. We understand that Depth Hermeneutics provides an intensity of experiences in the research field by valuing the experiences of individuals who participate in the construction of knowledge (CASTROSILVA; ANHAS, 2017).

Depth Hermeneutics is a theoretical and methodological approach that allows us to study symbolic forms and ideology by interpreting them. Both symbolic forms and ideology are socially, historically and culturally built, and are loaded with senses and meanings. To interpret an ideology is to make explicit the connection between the sense mobilized by symbolic forms and the domination relations that this sense helps to establish and sustain. There is interest, in this methodology, in investigating both the external and the internal structure and organization of symbolic forms and ideology.

We have used the Depth Hermeneutics approach in our research works in the Federal University of São Paulo in several studies on health conducted in the Vila dos Pescadores community in the municipality of Cubatão, state of São Paulo. This article refers to partial results of a doctoral research, granted in 2015/26500-5, funded by São Paulo Research Foundation (FAPESP).

In the Depth Hermeneutics proposal, the field of research is not only an object, but a fieldsubject, that is, the individuals who participate in the study mobilize senses, reflect, act: the field of study, dynamic, pulsates with life and is constantly changing. As the researcher enters 
the subject field, he comes to integrate the existing relations in a certain historical and social context and interferes with the field itself (THOMPSON, 2011). The researcher becomes involved with his object of study.

The three Depth Hermeneutics levels are: socio-historical analysis, formal analysis and interpretation/reinterpretation:

The socio-historical analysis consists in understanding the historical context of the object of study. For the construction of the results in this phase, participant observations were carried out, from which field diaries were subsequently produced. The Health Unit was the first institution with which the contact was made and from it contacts and observations were carried out in other places such as an NGO (cares for about 60 adolescents) in the neighborhood and a hip-hop group (with a variable number of young participants, ranging from 10 to 25). Throughout the research and extension work of UNIFESP in the community, since 2012, we have given priority to self-reports of current and past experiences in the Vila dos Pescadores. Study participants were 15-29 years old.

Formal Analysis proposes the understanding of the discourse of individuals and their symbolic and ideological forms, apprehending their senses and meanings. A field diary was produced for each observation. For the formal analysis, we opted for the Qualitative Epistemology proposed by González-Rey (2012), analyzing the meanings that are historically and socially constructed by the individuals in their dialectic relation with the context.

On the last level, Interpretation/Reinterpretation, new interpretations were produced critically and based on theories of the participant research (FALS BORDA, 2006; FREIRE, 2011; SCHMIDT, 2008; STRECK, 2016) and Social Psychology (LANE, 2004; SAWAIA, 2014; MARTÍN-BARÓ, 2017). It is called reinterpretation because it is understood that individuals already have interpretations about their reality.

By integrating the steps of formal analysis and interpretation/reinterpretation, some workshops were done on everyday issues in the community. Workshops are understood as "spaces of negotiation of meanings, with critical potential for collective production of meaning" (SPINK; MENEGON; MEDRADO, 2014, p. 32). Although they have been used as a methodological tool, the purpose of this paper is not to discuss them. Workshops are mentioned in this section because they are quoted throughout the highlights of the field diaries in the next section. They are also mentioned because through them it was possible to establish 
an approximation of the senses and interpretations attributed by young people to the ways of living in the community.

In the next section, due to the use of diaries that translate the experience of the main author of this article, the results will be discussed in the first person. The Vila dos Pescadores community was the place where I conducted another research (2013-2015), which aimed to understand the processes of building social participation of young people in that context (ANHAS; CASTRO-SILVA, 2017). It is also where we have, since 2012, together with our research group of the Laboratory of Studies on Social Inequality, developed research at scientific initiation, master and doctorate levels. In addition, since 2015 we have carried out an extension project in the area of human rights and in partnership with a Non-governmental Organization and a Health Unit. It has been a constant exercise of bringing university and community closer.

\section{RESULTS AND DISCUSSION}

I met the participants of my study again, especially in the context of the Non-governmental Organization where I started my research. The Non-governmental Organization was referred to by a Community Health Agent and there I could get very close to the reality experienced by the young people of the community. There is always distrust of the residents with regard to studies done in the community, because, as they say, "the community is left with nothing." Local media journalists also explore the site through images of violence and precarious living conditions. Researchers go to the community, gather the data they need, and never come back. They sometimes return to give some feedback. These situations of distrust reiterate that the community wishes to count on the ethical and political commitment of researchers to the reality where they live, to their lives.

My presence in the community, as a researcher, has shown other possibilities for commitment and participation, making me feel welcomed and cared for. This was the case when I got sick and had to stay away for a month from the activities developed in the field due to hospitalization.

During my stay at the hospital, I used to receive messages from the Psychologist and the Caregiver from the Non-governmental Organization always showing concern and support. I was quite excited to return and as 
soon as I arrived, on my first day back, the teens were engaged in some activity. (Field Diary, 05.16.2017).

Being present in the daily lives of young people provided me with the opportunity to get to know other spaces beyond the Non-governmental Organization I was already familiar with and, in a way, follow the dynamics and changes occurring in the neighborhood. One young man from the Non-governmental Organization invited me to meet the hip hop group of which he is a member. In the group I met again some participants of my master's research, because some of them took capoeira classes, the field of my research. Capoeira classes have ended, but the hip hop group still meets at the same place, the Community Center.

The volunteer hip hop instructor is a young man who has already participated in my master's research. He was a member of the capoeira group. He remembered me and authorized my observation. Jokingly, he even asked if I would like to talk to the students, because my presence in the community indicates that I want to talk. (Field Diary, 06.01.2017).

I made some remarks about the hip hop group. I talked about how, from the first day, I felt welcomed in the group, even knowing few people. The young man in the group said that they are a family, cultivate friendship and intimacy. Such characteristics, he said, are also present in their Whatsapp group. (Field diary, 07.06.2017).

The quality of the bond built at other times allowed me to interact with the hip hop group. This is not to say that the instructor would not allow me to do my research if it was the first time I was in the community center. It means recognizing the role of researcher as one who walks along with the community, a situation often illustrated when I heard several times that I am "part of the family", both in the Non-governmental Organization and in the group. A study with a participant approach requires immersing oneself in the daily life of the people by appropriating oneself ethically, historically and politically of their everyday life and context (STRECK, 2016).

However, this involvement and participation pose several ethical dilemmas (CASTROSILVA; MENDES; NAKAMURA, 2012). It is necessary to always position oneself, because the role that people can attribute to the researcher is often out of control. The roles assigned to me were linked to people's expectations and longings.

It is interesting to note the various roles that people attribute to us. It is the mother who walks by me in the alleys of the village and calls me "teacher". It is the young man who calls me "little school psychologist". It is the old man who gives me the role of "consultant". It is the young people who put me in the role of "friend". And everything is always very intense... (Field Diary, 11.23.2017). 
However, these roles that have been assigned to me have to do with the practices undertaken during the fieldwork. The feedback given by the people in the attribution of these roles allow to reflect on the practice, that is, they bring the possibility of ethically reflecting on the constructed relations. I would like to dwell a little on the roles of reflecting on social relations in the fieldwork.

In the context of the Non-governmental Organization, I was sometimes called a teacher. I proposed workshops in the area of sexuality and environmental education, for example, which put me in a role of facilitator, but interpreted as the role of teacher. However, it is important to reflect on the practice in order that certain roles do not reiterate asymmetries in the relationships built with the study participants.

The Non-governmental Organization Caregiver and I developed an activity with adolescents in the line of environmental education. We make homemade soap with used oil. We asked young people to bring used oil from home. We took the recipe on the Internet and everyone watched the video of how to prepare the product. They carefully watched the video of a youtuber. The idea was to promote a workshop in which they were also facilitators. The Caregiver and I did not want to be the "technicians", but only to support and cooperate in the execution of the task. And it worked. All of the 20 adolescents participated actively and lively. We managed to create a relaxed atmosphere. They all sat around the bucket and took turns stirring the mixture. They supervised each other's work and helped when someone felt tired. Teamwork was well articulated. One of the girls proposed naming a brand for our soap. The name chosen was "Nossabão" (oursoap). (Field Diary, 07.04.2017).

The name chosen for the soap is related to the methodology used to make it, referring, through the pronoun 'our', to the idea of collectivity. It should also be noted that the workshop's proposal was related to the activities carried out by the Non-governmental Organization in relation to the environment. The adolescents were, at that time, attending to lectures by technicians and engineers. The workshop proposal emerged as a possibility of exercising autonomy in which the adolescents would not have to passively listen to some scholar of the environmental issue, as it had been happening. In this sense, research can join the needs of the context without losing sight of its objectives.

The work of group dynamics and workshops, as the methodology of my doctoral research, also led people to call me "little school psychologist", because they were similar to the activities held by the institution's Psychologist. "Little school" is the affectionate nickname they gave to the Non-governmental Organization. 
As we have been saying, involvement and participation in the daily lives of people in the community raise some ethical dilemmas that require positioning. In the extract below, a situation is brought in which I was asked to evaluate the work of some Non-governmental Organization professionals in order to make decisions about whether or not they should stay in the institution.

I felt quite embarrassed even after the conversation. I wish I had not been put in that situation. I feel closely identified with the project, the young people and some Non-governmental Organization Caregivers. However, I considered important to emphasize, not with such words, that my role is that of a researcher rather than of a consultant. I think I felt embarrassed too because I do not believe I could not listen to his distress. He seemed very worried about a number of situations and it is not easy to manage an institution with the demands that exist in the territory. I felt a little frustrated that I had not been able to empathize with him. I do not think I acted coldly, but I was much more concerned to say that $\mathrm{I}$ was there doing research. (Field Diary, 11.23.2017).

I emphasize the confidence that allowed to assign me the role of "consultant". The relationship of trust is established based on the links and methodology of participant research. For a research to be feasible, people need to trust the researcher. Such trust is built gradually from the involvement and participation in the spaces of a given community. The idea of trust illustrates somewhat the notion of friendship when young people say they consider me a friend.

By the way, I have received this type of feedback from the participants of my study, which makes me reflect on my role as a researcher in a participatory perspective. Recently, hip hop young people came to ask me if I'm going to continue to attend their training when my research is over. When I said yes, they told me "it's because we have confidence in you, we got used to you here, it's a friendship already". I was invited to give singing and guitar lessons to hip hop guys as a way for me to continue to attend the training and, as they always say, to "add knowledge." (Field Diary, 11.23.2017).

Brandão (2012) retakes the notion of friendship contained in the writings of Aristotle, referring to the collective and political dimension of it. There is no citizenship without friendship and it has as its purpose the common good. In order for friendship to occur, according to the author, people need to approach each other, to build mutual knowledge and to wish each other well. In the context of the hip hop group, as we say, it is possible to identify the existence of friendship. At first, at the invitation of a young man, I approached the group. In a second moment, we collectively thought about how to build something together. 
I spoke about the proposal of my doctorate in greater detail. They again showed themselves open to research. I also spoke about the possibility of filming a documentary about the group and its history. That excited them a lot. It was the beat box teacher who most communicated with me, saying he loved the idea and opening the doors of the group for the realization of the research and the documentary. (Field Diary, 07.04.2017).

The idea of producing a video was mine, but it was related to the group's aspirations. It was a way I found to produce knowledge in conjunction with the study participants, taking into account that the script and structure of the video were developed by the young people themselves. They decided that they would do interviews with the members of the group and the script of the questions was done collectively in a workshop format. The places where the scenes were recorded were chosen by themselves. They chose places where they have some affective identification. To share responsibilities with young people is in line with what Fals Borda (2006) proposes when he refers to the need to share research tasks and tools with study participants.

One of the places chosen for the interviews was the train bridge. It is a railing bridge that connects the city of Cubatão to the port of Santos. It is a place where young people swim in the river, practicing jumps off the bridge. Being in the community poses some risks and facing them with the study participants makes it an intense experience.

During the first take, however, an interruption took place on the account of the traffic-working boys. While the beat box teacher was telling how he joined the hip hop group, a group of about 5 boys rushed toward us holding their little radios and one of them held a revolver. I felt a strong apprehension. We had already passed by them on the way to the tracks. They were about 40 meters away from the recording site. They did not address us, they seemed to be concerned about another situation, probably with the police. Even so I was afraid. They got into the woods aside the tracks while one of them lurked holding a radio. (Field Diary, 09.22.2017).

It was the young man who calmed me down and said that it would be no problem to continue the recording. Being in the community poses some risks. Participating in the daily life of the community means taking some risks together with the study participants, which makes it an intense experience. Risks are experienced in different ways. As we have discussed in Laboratory of Studies on Social Inequality, being embedded in a community in social vulnerability makes us temporarily vulnerable.

The risk we have been exposed to is not commonplace for me, since I live in another neighborhood of the same city, but for the residents of Vila dos Pescadores it is something that happens frequently. The episode also shows how contradictory reality is, for one of the 
purposes of making the video for young people is to deconstruct certain stereotypes of a violent place and show how powerful and creative the community is.

Although potentialities are prominent, much is said about youth involvement with drug trafficking and crime, so asking someone in the community about the young people is hearing responses related to these issues (ANHAS, 2017). Being in the community and being affected by the field and study participants led me to an unexpected reunion. A Caregiver from Nongovernmental Organization had already told me that one of the boys who participated in my research was involved in drug trafficking, but I could see the fact by experiencing a situation of fear and tension.

The Caregiver's answer was emphatic: "He's dealing drugs." I was paralyzed. I got very upset. When I was leaving, alone in the car, I cried. Like I do today with the young people, I played a lot of table tennis with this boy, who is now 17 years old. The radio, the backpack and the shame as he saw the Non-governmental Organization employees, looking down, are the clear proofs that he is really dealing drugs. I was wondering what happened to that boy's dreams of becoming a soccer player and to live in a better neighborhood or city. (Field Diary, 06/23/2017).

On another occasion, during an interview of a community leader who lives next to a trap house, resulting from Laboratory of Studies on Social Inequality research activities, the police started an operation in the neighborhood. In the movement of the traffic boys as a result of the police helicopters flying over the community, I could see the young man who took part in my research wielding a rifle.

We were afraid. We could not focus. That way we got a little closer to that reality. The reality of violence. We got a little closer, for no matter how intense the violence of the war between police and trafficking, in which the population is a hostage, we are not abused daily by the various types of violence existing in the village. The people in the Vila dos Pescadores live through this instability and various other types of violence. It's just being closer, because we could choose to walk away from the place where so many others stayed without the same power of choosing where to go. (Field Diary, 09.26.2017).

While such situations indicate conflicts and affects such as fear, they point out some differences between researcher and research participants. Faced with this tense situation, I was able to perceive a life in which it is difficult to act; one can only react. It was a situation that made me understand in practice what I have always been told: it's "the police that brings violence to the community". For a moment it was possible to feel and think the same. "Everything" was in peace until the police arrived. But the point is that in the Vila dos 
Pescadores "everything" is never in peace. The people there are never in peace. I was not in peace.

These affects lived during fieldwork allow sharing with the other study participants, in a perspective of politicization which translates into a commitment to the other (SAWAIA, 2011). From the affects arises the possibility of exercising dialogues on how to express the understanding of circulating affects related to the social and historical conditions of the community, generators of good and bad encounters.

The commitment to the other emerges as a condition for any participatory and affective praxis, because only through collective mediation does individuality emerge. All capacity for meaning and sense making cannot exist as a solipsistic expression of an individual: thought, language, feeling and action are built up in good encounters with other subjects in a zone of potential development of subjectivities that is also the locus of encounters between society and history. (BRANDÃO, 2012, p. 183).

Some conversations about the hip hop group and the community in which they are included may have provided reflections on their identification with the place they live and how they recognize themselves in it. Motivated by the production of the video, but also by the subject, we could discuss the involvement in drug trafficking from other perspectives related to history, inequality, and citizenship.

They seemed instigated with the idea of demystifying certain social categories. Mobilized by the conversation, they said that not every poor person will become a criminal. One of the boys remembered the time when he lived on stilts in the community and that, nevertheless, he did not become a drug dealer or drug user. The making of the video also appears as a way of writing a history of Cubatão, since much of this is told by industries and not by people who experience the daily life of the city. In this way, apart from demystifying some stigmas, it aims to show one Vila dos Pescadores that the rest of the city does not know: a powerful community! (Field Diary, 09.04.2017).

In addition to these situations providing a very intense field activity, the fieldwork does not have to be closed for the feedback to take place. The research, as understood by GonzálezRey (2012), is a constructive process. In this sense, feedback can be given during the fieldwork, in informal conversations or workshops, for example. It is possible that such feedback or interpretations increase the degree of reliability (STRECK, 2016) and also actively include people in the process of knowledge construction. 
I resumed asking about the issue of identification with the Vila dos Pescadores. I have cited examples from other outlying communities where their residents refer to the community with pride, extolling the place where they live. This is something I do not notice in these young villagers. In their opinion, there is nothing to defend in the Village, and entering into discussions with people from other neighborhoods, even if they are in social vulnerability too, is certain defeat for lack of arguments to stand up for the Vila dos Pescadores. But after discussing, they pointed out that good things in the community refer to friendships, family and intimacy. (Field Diary, 06.05.2017)

My research findings allowed me to ask young people about a situation I had been experiencing and to share my feelings with them. From my inquiry and our discussion, they recognized some positive aspects of the Vila dos Pescadores concerning social relations, seen as potent.

I gradually realized that some young people are interested in research as a way to get to know and learn a bit, as they gave me the feedback that they are learning. They demonstrate knowing the goals of the study, so that they can give me information about certain historical events in the community and I can talk more properly with older residents. Moreover, they are active participants in the process of building knowledge and perceive themselves in this condition, indicating people in the community who they think I should meet and interview.

The young man asked me why I chose that village to do the research. I told him again about the history of UNIFESP's presence in the neighborhood and my interests in researching youth. He said he's learning a lot from me too. He cited as an example the brief conversation with a former neighborhood president in which he was with me. He said he had no idea about the former president's work and many other things about the people in the neighborhood. He also mentioned he did not know that the residents' association was founded by women, in what was called the Mothers Club. (Field Diary 22.11.2017).

On the way, the young man suggested a larger route so we could continue the conversation about crime in the Vila dos Pescadores. He wanted to tell everything he knew about drug dealing in the community, especially the story from the 2000s, when the PCC had not even taken control in the neighborhood. I noticed an interest in telling these stories to better equip me to interview a community leader who had already been involved in trafficking. Ask him about it, he kept saying. (Field Diary, 22.11.2017).

This research approach involves participation, and participating is engaging intersubjectively, taking into account the exercise of affectivity, dialogue and otherness. We believe that involvement with the community and the other is positive and there is no neutrality in participation (SAWAIA, 2001). Of course, such participation poses ethical dilemmas and it is 
therefore important to reflect on practice and theory in the sense that we do not produce knowledge aseptically, but ethically and politically committed.

\section{FINAL REMARKS}

Bonding during my fieldwork reinforce the notion that the researcher also undergoes ethical training. Through the willingness to reflect on their ways of living, feeling and thinking, it is possible to meet the others in their ways of living, feeling and thinking.

Personal involvement cannot ever be confused, for the researcher is not the other. In this sense, the ethical dilemmas of research demand positions and reflections on the role played in the fieldwork. Being together and walking along with the community does not mean to "mix" with the other, but to help make their goals and needs clear by recognizing the social place one occupies.

I conducted my research in a neighborhood of a medium-sized city, where the great majority of dwellers know each other. I was born in Cubatão, just like the participants of my study. However, I am not a resident of the Vila dos Pescadores, but this does not exclude the possibilities of building bonds of friendship along the lines of this text as approximation, policy, building knowledge and willing the good of the other, which expresses itself in solidarity, so fragile in our context of extreme individualism.

It should also be said that the time for building these bonds will never match the time of academic bureaucracies. Accelerated intellectual production reproduces the capitalist logic, which is one of those responsible for the breaking down of social ties and relations.

\section{REFERENCES}

ANHAS, D. M.; CASTRO-SILVA, C. R. Sentidos atribuídos por adolescentes e jovens à saúde: desafios da Saúde da Família em uma comunidade vulnerável de Cubatão, São Paulo, Brasil. Saúde e Sociedade, São Paulo, v. 26, n. 2, p. 484-495, jun. 2017. Doi: 10.1590/s010412902017169735.

CASTRO-SILVA, C. R.; ANHAS, D. M. Potência de ação do agente comunitário de saúde: contribuições da pesquisa participante e da hermenêutica de profundidade, 2017. Disponível em: http://proceedings.ciaiq.org/index.php/ciaiq2017/article/viewFile/1461/1418. Acesso em: mar. 2018. 
CASTRO-SILVA, C. R. et al. Participação social e a potência do agente comunitário de saúde. Psicologia \& Sociedade, Belo Horizonte, v. 26, n. spe 2, p. 113-123, 2014. Doi: 10.1590/S0102-71822014000600012.

CASTRO-SILVA, C. R.; MENDES, R.; NAKAMURA, E. A dimensão da ética na pesquisa em saúde com ênfase na abordagem qualitativa. Saúde e Sociedade, São Paulo, v. 21, n. 1, p. 32-41, mar. 2012. Doi: 10.1590/S0104-12902012000100005.

CASTRO, L. R. Juventude e socialização política: atualizando o debate. Psicologia: Teoria e Pesquisa, Brasília, v. 25, n. 4, p. 479-487, dez. 2009. Doi: 10.1590/S0102-

37722009000400003

CRUZ-GARCETTE, L.; ABREU-BALLESTER, G. M.; BRANDI-BRUNA, L. S. La relación intersubjetiva en la construcción del conocimiento. Magis: Revista Internacional de Investigación en Educación, v. 7, n. 14, p. 85-98, 2014. Doi: 10.11144/Javeriana.M714.LRIC.

DARDOT, P.; LAVAL, C. A nova razão do mundo: ensaio sobre a sociedade neoliberal. São Paulo: Boitempo, 2016.

FALS BORDA, O. Aspectos teóricos da pesquisa participante: considerações sobre o significado e o papel da ciência na participação popular. In: BRANDÃO, C. R. (org.). Pesquisa Participante. São Paulo: Brasiliense, 2006. p. 42-62.

FREIRE, P. Pedagogia do oprimido. Rio de Janeiro: Paz e Terra, 2011.

HORTA, N. C.; SENA, R. R. Abordagem ao adolescente e ao jovem nas políticas de saúde no Brasil: um estudo de revisão. Physis, Rio de Janeiro, v. 20, n. 2, p. 475-495, 2010. Doi: 10.1590/S0103-73312010000200008.

LANE, S. T. M. A Psicologia Social e uma nova concepção de homem para a Psicologia. In: CODO, W.; LANE, S. T. M. (org.). Psicologia social: o homem em movimento. São Paulo: Brasiliense, 2004. p. 10-19.

MARTÍN-BARÓ, I. Crítica e libertação na Psicologia: estudos psicossociais. Petrópolis: Vozes, 2017.

MENDES, R.; FRUTUOSO, M. F. P.; SILVA, C. R. C. Integralidade como processo intersubjetivo de construção de práticas em território de exclusão social. Saúde Debate, Rio de Janeiro, v. 41, n. 114, p. 707-717, set. 2017. Doi: 10.1590/0103-1104201711403.

MORAES, R. C. P. et al. Pesquisa participante na Estratégia Saúde da Família em territórios vulneráveis: a formação coletiva no diálogo pesquisador e colaborador. Trabalho, Educação e Saúde, Rio de Janeiro, v. 15, n. 1, p. 205-222, abr. 2017. Doi: 10.1590/1981-7746-sol00035

ONOCKO-CAMPOS, R. Fale com eles! O trabalho interpretativo e a produção de consenso na pesquisa qualitativa em saúde: inovações a partir de desenhos participativos. Physis: Revista de Saúde Coletiva, Rio de Janeiro, v. 21, n. 4, p. 1.269-1.286, dez. 2011. Doi: 10.1590/S0103-73312011000400006 
SAWAIA, B. B. Participação social e subjetividade. In: SORRENTINO, M. (org.), Ambientalismo e participação na contemporaneidade. São Paulo: EDUC/FAPESP, 2001. p. $115-134$.

SAWAIA, B. B. Transformação social: um objeto pertinente à Psicologia Social? Psicologia \& Sociedade, Belo Horizonte, v. 26, n. spe2, p. 4-17, 2014. Doi: 10.1590/S010271822014000600002

SAWAIA, B. B. O sofrimento ético-político como categoria de análise da dialética exclusão/incluso. In: SAWAIA, B. B. As artimanhas da exclusão: análise psicossocial e ética da desigualdade social. Rio de Janeiro: Vozes, 2011. p. 99-129.

SCHMIDT, M. L. S. Pesquisa participante e formação ética do pesquisador na área da saúde. Ciência e Saúde Coletiva, Rio de Janeiro, v. 13, n. 2, p. 391-398, abr. 2008. Doi: 10.1590/S1413-81232008000200014.

SILVA, A. A.; SOUZA, K. R. Educação, pesquisa participante e saúde: as ideias de Carlos Rodrigues Brandão. Revista Trabalho, Educação e Saúde, Rio de Janeiro, v. 12, n. 3, p. 519-539, dez. 2014. Doi: 10.1590/1981-7746-sip00012.

SPINK, M. J.; MENEGON, V. M.; MEDRADO, B. Oficinas como estratégia de pesquisa: articulações teórico-metodológicas e aplicações ético-políticas. Psicologia e Sociedade, Belo Horizonte, v. 26 n. 1, p. 32-43. 2014. Doi: 10.1590/S0102-71822014000100005.

SPOSITO, M. P.; CARRANO, P. C. R. Juventude e políticas públicas no Brasil. Revista Brasileira de Educação, Rio de Janeiro, n. 24, p. 16-39, dez. 2003. Doi: 10.1590/S141324782003000300003

STRECK, D. R. Metodologias participativas de pesquisa e educação popular: reflexões sobre critérios de qualidade. Interface: Comunicação, Saúde, Educação, Botucatu, v. 20, n. 58, p. 537-547, set. 2016. Doi: 10.1590/1807-57622015.0443

REY, F. G. Pesquisa qualitativa e subjetividade: os processos de construção da informação. São Paulo: Cengage Learning, 2012.

THOMPSON, J. B. Ideologia e cultura moderna: teoria social e crítica na era dos meios de comunicação de massa. Petrópolis: Vozes, 2011.

TRASSI, M. L.; MALVASI, P. A. Violentamente pacíficos: descontruindo a associação juventude e violência. São Paulo: Cortez, 2010.

Submetido em 27 de março de 2019.

Aprovado em 26 de maio de 2019. 